\title{
HAYNE CONSTANT, CB, CBE, MA, FRS, Fellow
}

\author{
1904-1968
}

$\mathrm{T}$

HE AERO ENGINE world has produced a number of men of outstanding ability and force of character. Hayne Constant, who died on 12th January, having been in indifferent health ever since his retirement, was one of them. He will be chiefly remembered as a pioneer and prime advocate of the axial compressor type of turbine engine which now dominates aeronautics, but he was also the creator of Britain's centre of aero engine research at Pyestock. He planned the original installation there at the beginning of the war and was Director of NGTE during the formative period 1948-1960.

He was awarded the Busk Memorial Prize of the Royal Aeronautical Society in 1932, the James Clayton Prize in 1947 and the Aeronautical Society's Gold Medal in 1963. He was elected a Fellow of the Royal Society in 1948, and created CBE in 1951, CB in 1958.

Hayne Constant was born at Gravesend in 1904 and spent his childhood in Folkestone where his father was a dental surgeon. He was educated in King's School, Canterbury and at Queen's College, Cambridge, where he took Part 1 of the Mathematical Tripos and the Mechanical Sciences Tripos and also did a year's postgraduate research. He joined the Royal Aircraft Establishment in 1928 and for the next six years worked in the Engine Department in a number of fields, including problems of aircraft and engine vibration. It was his paper on aircraft vibration, reported in the JourNal of March 1932, that led to the award of the Busk Memorial Prize.

It is not known how soon Constant's interest in gas turbines was aroused. He must have met A. A. Griffith almost at once and it cannot have been long before he learnt of the epoch-making ideas which Griffith had advanced in 1926 when he outlined his aerofoil theory of turbine design. But in spite of the success of the early experiments which followed Griffith's first proposals for using a gas turbine as an aircraft powerplant, the project was not approved and there was a period of some six years during which the gas turbine work at RAE was at a stop. For both of them it was a period of frustration and disappointment and Constant sought new pastures in 1934, spending two years on secondment to Imperial College of Science and Technology.

In 1936, although there was no fresh scientific evidence to change the prospects of the enterprise, the gathering war clouds had created a new situation and a research programme on axial compressors and turbines was initiated. Griffith and Constant were now working together until Griffith left RAE in 1939, and the five year period 1936 to 1941 was Constant's great creative period of individual research. During these years great strides were made in analysing the thermodynamic characteristics of turbine engines in the various forms of simple jet, compound jet, ducted fan and propeller engine, in exploring the performance of multistage axial compressors and turbines, in studying the novel combustion problems, in building up a research team and planning new facilities. The programme was one in which industry, from the outset, played a substantial part, for while RAE undertook the design and research, industry, notably the Metropolitan Vickers Company, undertook most of the manufacture and testing. This period came to an end in 1941 when Constant undertook wider duties as Head of Engine Department with

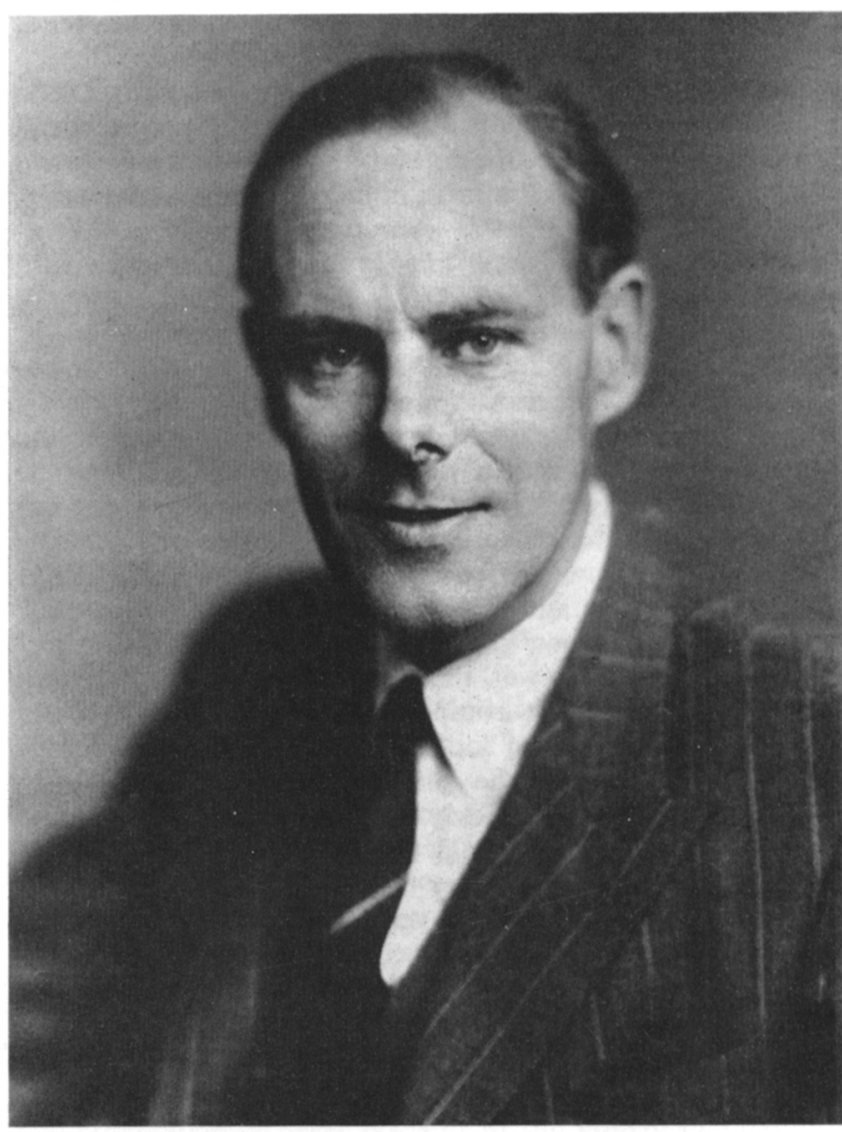

manifold responsibilities for the reciprocating engines with which the war was being fought.

The summer of 1941 brought dramatic change when it was decided by Sir Stafford Cripps that the gas turbine team at RAE was to be merged with Whittle's organisation, Power Jets, in a Government-owned company, Power Jets (R \& D), of which Dr. Harold Roxbee Cox, now Lord Kings Norton, became Managing Director. This was a difficult period for, although the work continued to expand, the situation was an uneasy one and in 1946 the company's research and development functions and facilities were transferred to a new Government establishment, the National Gas Turbine Establishment, under the direct control of the Ministry of Supply.

Two years later Constant became Director of the establishment with the task of consolidating its facilities at Pyestock and building it up as a new centre of Government research in the rapidly growing field of gas turbine technology. This was, I think, the second great period of creative activity in which the problems of welding together the separate teams into a new research organisation, of holding the balance between the rival claims of various gas turbine applications, of obtaining the costly test facilities required for the rapidly advancing engine technology, had all to be solved. At the beginning of the period the first jet propelled aircraft were in service with the RAF; by the end of it the gas turbine was the dominant aero engine for all powers over about $500 \mathrm{hp}$ and for almost all applications. The science of gas turbines had advanced from the 
elementary treatments and improvisations of the early days to a high degree of sophistication. NGTE had acquired a world-wide reputation.

The final phase of Constant's career was as Scientific Adviser to the Air Ministry, and Chief Scientist (RAF), Ministry of Defence, tasks which he executed with distinction but not without some reluctance, for his heart was always in research and he had little stomach for the feuds and disputes of Whitehall.

I first met him in 1941 when I had the good fortune to be attached by A. H. Hall, then Chief Superintendent, RAE, to the turbine division of the Engine Department which was then being built up under Constant's leadership. Some eight of us shared a room of modest size and off this Constant had a small glass cubicle of an office with bare space for a table and chair. Looking back it is hard to conceive how we managed in these cramped quarters, especially as one of Constant's habits was to stalk slowly up and down wrapped in thought.

For him it was a time of high promise for, after the delays and frustrations of the early thirties, gas turbine projects were now being strongly supported, the first axial engine which he had inspired and was responsible for (the Metro-Vick F2 engine, later known as "Beryl") was about to have its first run and the emergence of a continuous flow engine opened up new prospects for research on its component process. He was then 36 , tall, rather gaunt, with light hair and a dark complexion, a hard mouth but a rather gentle withdrawn look (he did not seem to change much with the years); he wore the mantle of a natural authority. For one quickly recognised his intellectual mastery, his formidable dialectical powers, his laconic and often mordant wit.

But it was not until many years later that I got to know him properly. To some extent this was due to the circum- stances of the time; we were all so deeply absorbed in our work and were living, widely dispersed, under such constraints of wartime shortage that there was little opportunity left for personal relationships. But it was partly a result of Hayne's aloofness which established a pattern in the group that no one else was able to break down. For he had a quality of reserve which was not easily penetrated. I had no conception then of the gentle and indeed simple man that hid behind the rather forbidding exterior. The fact is we were all slightly scared of him and, as I found out later, this applied equally to his superiors.

It was in the fifties, when we were building up the new establishment at Pyestock, that I began to get to know him and to appreciate what a rare person he was. His outstanding characteristics, I think, were the single-mindedness and consistency of his policy in research, and his clarity of thought and expression; these qualities made him contemptuous and intolerant of muddled thinking and compromising opportunism, leading sometimes both in public and private to the most devastating retorts, and earning him the reputation of being a difficult customer. But it was pomposity and pretentiousness that he found hardest to stomach and these were the manifestations that brought forth the most destructive rejoinders. He was, in short, fastidious, and found difficulty in concealing his distaste for anything that fell short of his high standards.

But behind the defences of his essentially solitary nature there was, as his friends discovered, a singular charm and gentleness. His death leaves a gap that will never be filled and it is a particular sadness that his last years were clouded; for working in London was a grief to him and enjoyment of his retirement was spoilt by failing health.

-PETER LLOYD, Fellon: 